\title{
Teaching Translation From the Perspective of Skopos Theory
}

\author{
QI Jian-tao \\ Ningbo Dahongying University, Ningbo, China
}

\begin{abstract}
Translation for language teaching is different from general translation which is characterized with Faithfulness, Expressiveness, and Elegance. The differences lie in vocabulary, structure, and discourse. The extreme emphasis of translation skills will make it hard to learn certain language elements for the English learners. The paper makes an analysis on the three levels of translation for language teaching from the perspective of Skopos Theory, aiming at drawing attention from the translation teachers to care more about students' demands of learning language elements through translation.
\end{abstract}

Keywords: translation for teaching language, literature translation, differences

\section{Introduction}

Skopos Theory points out that all the translation must follow the top ranking principle-purpose-oriented principle. Translation functions in target language context and culture according to the way that target language receptors are expecting. A translation action is always determined by its purpose, stating that any translation action is purposeful. In English teaching, we often encounter two types of translation: Sentence and textual translation are used to promote students' vocabulary use and syntactic structure, which is called "translation for teaching English language". The other type is called "literature translation" or other types of translation based on the principle of "Faithfulness, Expressiveness, and Elegance". Since two types of translation have various purposes, they way of doing the job should also be different from one another, which requests teachers of English should treat with the two types of translation in different ways. Only if the teachers do this way can different purposes of translation be reached respectively.

\section{The Way to Deal With Words}

There are three basic rules for Skopos Theory, among which the fidelity rule believes that there exists inter-textual coherence between source text and target text. That is to say, in all theories of translation, target text shall be faithful to the source text, which is a rule to be adhered to. But the degree and way of fidelity depend on the purpose of translation and understanding of translators for original text (Nord, 2001). Since helping students to understand and master the vocabulary is the main purpose of teaching translation in general English teaching, the teachers of English should try to achieve equivalence of set phrases and idioms in the progress of translation. In other words, they should teach the students to translate the words with its linguistic meaning. Therefore, when doing translation exercises, the translators should highlight the salient linguistic meaning of words and phrases as completely as possible, which means that they should just achieve the equivalence of linguistic meaning, reach "faithfulness and expressiveness", and not stress "elegance" too much

QI Jian-tao, associate professor, master, College of Humanities, Ningbo Dahongying University. 
and try to avoid excessively amplifying, deleting, reversing, or transferring the meaning of words.

Eg. Source Text: “...I'll count three hundred. That is five minutes and not one of you is to move a muscle. Those who move will forfeit 50 Rupees. Ready!” (ZHAI, College English, 2013).

Chinese translation: “......我数三百一也就是五分钟一你们谁都不许动一动。动者将罚款 50 卢比。准 备好!”

According to the literature translation standard "Faithfulness, Expressiveness, and Elegance", the reference translation keeps the spirit loyally and it reads very well. It is a wonderful translation. However, the audience of this translation are students, and the aim of the translation is to make students master the usage of uncommonly used words, like "forfeit". In order to reach the requirements of "elegance" in literary translation, the translator translates the word into "penalty", but "penalty" cannot express the linguistic meaning of "forfeit", it also may be confused with "to be fined" easily, so students cannot master the meaning and usage of "forfeit" from this translation. Because according to Oxford Advanced Learner's Dictionary, its meaning is: "to have to give something up because some agreement or rule has been broken, or as a punishment". If it can be translated into “谁动谁就交出50卢比来” with the purpose of vocabulary learning, it can express the linguistic meaning of a word more accurately, and help students master usage of the word by translation comprehension.

\section{The Way to Deal With Grammar}

As students who are learning English as a foreign language, grammar structures are important for them, especially in the situation of using Chinese as a contrast. They learn gradually to understand the differences between two languages, and gradually understand and master language structure through the translation. According to the principle of intra-textual coherence of Skopos Theory, under the conditions that translation is readable and acceptable, as a way of language teaching, translation should try to keep the original structure and grammar features, and make the students able to understand the heterogeneity of foreign language (Newmark, 2001). Such as "We won't understand the love of our parents until we ourselves become parents". Some translators translate it into “不当父母不知父母恩”. After using the translation skills such as sequence change and variation translation, the translated version expresses the meaning of the original text accurately and concisely. But as a way of training of "not... until" structure for language teaching, in addition to obtaining the semantic information of the sentence, students cannot obtain or master the grammar structure of the language in translation, thus affecting the study of grammar structure. If it is translated into “直到当了父母, 我们才明白 父母对于我们的爱”, it can let the grammar structure be trained in the translation version.

Eg. Source Text: "Walk down some of the streets of Newark, N. J. and you'll encounter trash, graffiti and boarded-up store fronts".

Chinese translation: “在新泽西的尼瓦克市一些街道上，垃圾、画得一塌糊涂的墙壁，把门面用木板钉 起来的商店随处可见”。

Seen from the translation criterion of "Faithfulness, Expressiveness, and Elegance", the Chinese translation is very good and can be regarded as a good translation. However, for the students who aim at learning cognitive grammatical structure "do something and you will...", the corresponding Chinese translation has been submerged and not been translated correctly, which is not conducive for students mastering the structure. If you use this example to teach students English, you should try to do it on the basis of serving the translation purpose, and translate the source sentence into “如果你沿着新泽西泥瓦克市的一些街道走, 你会 
随处目睹垃圾，画得一塌糊涂的墙壁以及把门面用木钉钉起来的商店”, which is more conducive to improving students' language.

\section{The Way to Deal With the Discourse}

In literature translation, the translator often uses a variety of translation techniques and means to ensure the exquisiteness of the expression (Munday, 2004). As to the arranging the structure of the discourse, the context will be used as a means of translation so as to omit some words and structures. Namely, some words and grammatical structures will be hidden in the context of a passage. Even the way of literal translation is applied, the text still needs not to be translated word by word correspondingly and the meaning of the text can be appreciated by readers through the context. Although the translation conforms to the principle of "Faithfulness, Expressiveness, and Elegance" (ZHENG \& MU, 2007), it violates the basic purpose of using translation to guide students to master the knowledge of language. Because of its insufficient ability of reading the text, students cannot benefit from it.

Eg. (1) Source Text: "Outside, torrential rains are threatening to sweep my little house off the mountain slope..."

Chinese translation: “外面, 倾盆大雨真像要把我那摇摇欲坠的小屋冲下山坡......”

In the above sentence, the writer makes a detailed description of the fierceness of the rainstorm and the damage it has caused, and makes the translation have intra-textual function by arranging the structure of the whole text. So it is unobtrusive that the writer delete the structure- "threaten to do something", which makes translation fluent, and as the literary translation, it is also perfect. However, students can hardly benefit from the translation if it is used for teaching English. Since there is a rhetoric device of personification in the original text, so it is good for students' study if the whole structure is translated. Thus if the sentence can be translated as “外面，倾盆大雨像威胁着要把我的小屋冲下山坡......”, it will better serve the purpose of leaning language through the discourse translation for the students.

Eg. (2) Source Text: "In times of famine, if a well-fed man speaks scornfully of food, and advise a starving man at point of death to glut his hunger on the fragrance of flowers and songs of birds. "What are we think of him?"

Chinese translation: 如果在闹饥荒的时候, 一个吃得很饱的人说食物是无关紧要的, 倒要劝一个快 要饿死的人去欣赏鸟语花香, 对这种人, 我们该怎样看待呢?

As in the above case, If it is translated as: “在闹饥荒的时候, 如果一个吃得很饱的人鄙夷不屑地谈论 食品, 同时又劝告一个快要饿死的人用鸟语花香去充饥, 我们该怎样看待这种人呢?”, then the translation can help students master the usage of word group better, like the English phrase "speak scornfully of", etc.

\section{Conclusion}

From the above analysis, it can be seen that different purposes of translation may decide the form and the methods of translation, which is basic principle of Skopos Theory. Literature translation and translation for teaching language are the subdivision of translation. With the same source language, their translation might a little bit different from one another. That is because we translate according to the purpose of the job. We cannot say that one way is superior to the other, since they appear different just because they serve different purposes. Thus the procedure and the final form are also different. The final version of translations just reflects the differences in the purpose from the various perspectives. Literature translation pays more attention to 
comprehensive application of the various methods and skills for translation; it is the perfect expression for translation principles of faithfulness, expressiveness, and elegance. In translation for teaching English language, teachers should take students on foreign language acquisition into consideration when they do the translation exercises, so it is necessary to make the elements of language explicit which have been diluted, hidden, and dissolved deliberately in translation. So when students do translation practice and appreciate translation, they can feel more directly the differences between the two languages and better grasp the language features of English.

\section{References}

Munday, J. (2004). Introducing translation studies: Theories and applications. Shanghai: Shanghai Foreign Language Education Press.

Newmark, P. (2001). Approaches to translation. Shanghai: Shanghai Foreign Language Education Press.

Nord, C. (2001). Translating as a purposeful activity: Functionalist approaches explained. Shanghai: Shanghai Foreign Language Education Press.

ZHAI, X. J. (2013). On teaching translation. College English, 6, 32.

ZHENG, Y., \& MU, L. (2007). The development and status quo of translation teaching and research in China in 50 years. Journal of Guangdong University of Foreign Studies, 4, 45-46. 